DOI:

10.1038/nrmicro1627

Individually neither the fungus nor the plant can grow at temperatures exceeding $38^{\circ} \mathrm{C}$, but the symbiotic association allows both to survive at temperatures approaching $65^{\circ} \mathrm{C}$
SYMBIOSIS

\section{Three pieces in the puzzle}

Although the term symbiosis was first coined in the late nineteenth century, research into the relationships between organisms that intimately interact has only recently gained pace. Reporting in Science, Márquez et al. describe a tripartite association between a virus, a fungus and a plant that confers thermal tolerance on both the fungus and the plant.

In the system studied by Márquez et al., the fungus Curvularia protuberata had previously been shown to grow inside the root cells of the tropical hot springs panic grass Dichanthelium lanuginosum. Individually neither the fungus nor the plant can grow at temperatures exceeding $38^{\circ} \mathrm{C}$, but the symbiotic association allows both to survive at temperatures approaching $65^{\circ} \mathrm{C}$. How the fungus affected thermal tolerance was not clear.

Fungal viruses (mycoviruses) can reduce the virulence of fungal plant pathogens, so have a proven role in altering complex phenotypes. Suspecting that a third party might be involved in the intriguing C. protuberata-D. lanuginosum relationship, Márquez et al. looked for the signature of a mycovirus - large dsRNA molecules - in C. protuberata. They found two viral RNA segments and subsequently purified infectious viral particles from C. protuberata. The virus was named Curvularia thermal tolerance virus (CThTV).

Next the team investigated whether CThTV exerted any effect on the thermal tolerance phenotype. A C. protuberata variant that lacked virus was isolated. In a crucial experiment, Márquez et al. inoculated panic grass plants with $C$. protuberata either containing, or lacking, CThTV and tested for thermal tolerance. Plants colonized by virus-free C. protuberata rapidly shrivelled and died at high temperatures, which pointed to a role for the mycovirus in the modulation of plant and fungal thermal tolerance.

In order to test this hypothesis, the authors re-introduced purified CThTV into the cured C. protuberata strain. This new strain colonized panic grass and conferred heat tolerance, showing that heat tolerance was clearly associated with the presence of the mycovirus. Plants colonized with C. protuberata do not activate stressresponse systems that can damage cells, and it is plausible that colonizing fungi 'mop up' damaging reactive oxygen species (ROS), allowing plants to survive in stressful conditions. Although Márquez et al. were able to show that ROS was not detected in the leaves of plants colonized by C. protuberata, the effects of the symbiotic fungus on ROS levels were not altered by the presence or absence of CThTV. So the mechanism underlying thermal tolerance in this tripartite symbiosis remains to be clarified.

Only two other tripartite symbioses involving viruses, between insects, bacteria and bacteriophage, have been characterized so far. These findings show that such complex interactions might be more widespread than previously thought.

Susan Jones

ORIGINAL RESEARCH PAPER Marquez, L. M., Redman, R. S., Rodriguez, R. J. \& Roossinck, M. J. $A$ virus in a fungus in a plant: three-way symbiosis required for thermal tolerance. Science 63 , 545-558 (2007)

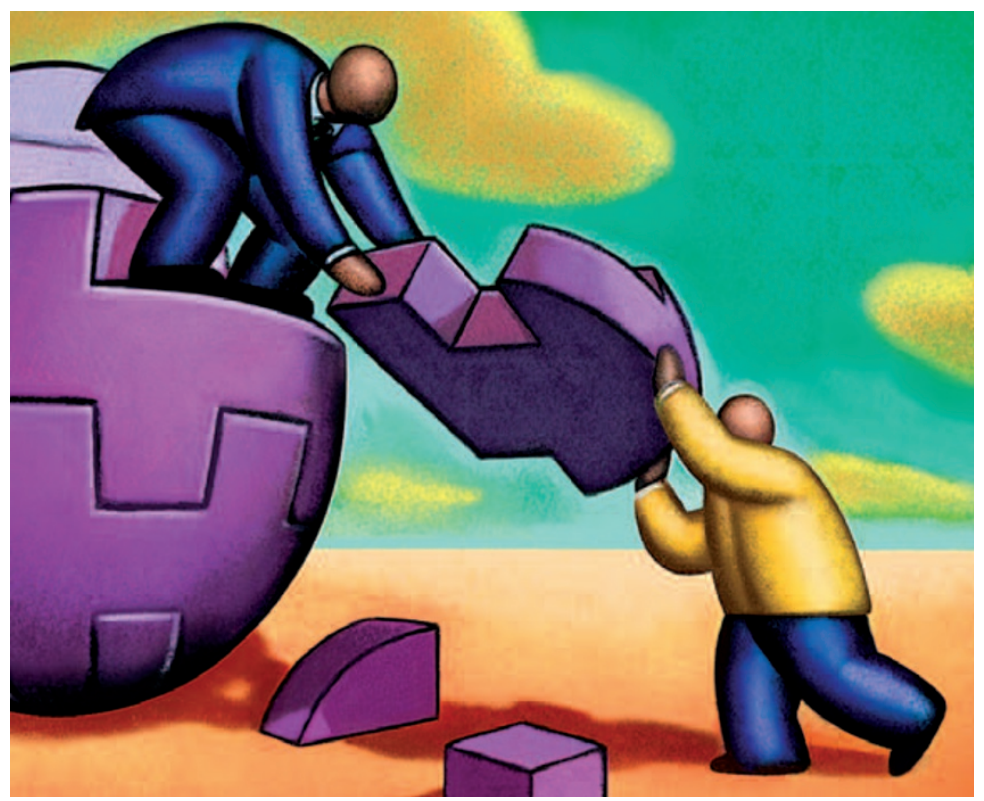

